\title{
The effects of distant professional development model on second grade teachers' instruction and students' quality of procedural papers
}

\author{
Zoi A. Traga Philippakos ${ }^{1}\left[\right.$. Ashley Voggt ${ }^{2}$
}

Accepted: 3 January 2021 / Published online: 25 January 2021

(c) The Author(s), under exclusive licence to Springer Nature B.V. part of Springer Nature 2021, corrected publication 2021

\begin{abstract}
The purpose of the study was to examine the feasibility and effectiveness of a distant-professional development model that supported the implementation of genrebased strategy instruction for procedural writing on second grade teachers' fidelity of implementation and students' writing quality. Participants were $84 \mathrm{~s}$ graders and four teachers who were randomly assigned to condition. Teachers completed an online workshop module prior to instruction, a survey on their instruction and confidence to teach writing, received coaching feedback during implementation, and were interviewed at pretest and posttest. Students wrote in response to two procedural topics at pretest and posttest, at maintenance, completed transfer tasks in science and in persuasion, were interviewed at posttest, completed a confidence scale, and standardized measures. Results showed that treatment teachers positively evaluated the PD and its components, taught with high fidelity, and positively commented on the instructional approach. Treatment students wrote papers of better quality at posttest and maintenance tasks, while there were no statistically significant differences at the transfer tasks, on students' confidence, and on standardized measures. Implications for professional development, practice, and research are further discussed.
\end{abstract}

Keywords Writing instruction · Procedural writing · Genre-based strategy instruction · Confidence · Professional development · Online PD · Writing PD

Zoi A. Traga Philippakos

philippakos@gmail.com; zphilipp@utk.edu

Ashley Voggt

Ashley.Voggt@tamucc.edu

1 University of Tennessee, Knoxville, USA

2 Texas A\&M University, Corpus Christi, USA 


\section{Introduction}

Reading and writing are critical literacy tasks that can affect both young learners in their academic careers and adults in their professional lives (National Commission on Writing in America's Schools and Colleges, 2003). Recent policies emphasized reading and writing connections and focused on writing instruction as a means to support understanding and promote critical thinking. In particular, the Common Core State Standards Initiative (CCSSI, 2010) echoing the National Assessment of Educational Progress (NAEP, 2009) set as an instructional expectation that students write to persuade, inform, and narrate. Within those purposes, learners respond to different genres that pose structural, linguistic, syntactic demands on their cognition and overall knowledge-base, often affecting their confidence.

In order for this knowledge about genres and writing skills to develop, instruction should be based on evidence-based practices. However, even though writing research provides specific recommendations about how to support writers and on "what works" in writing instruction, those instructional practices are not evident in classrooms (Cutler \& Graham, 2008; Gilbert \& Graham, 2010). Several factors have been identified for this lack of evidence-based practices on writing. One reason is teacher preparation. Universities and colleges have a great responsibility as teachers share they are ill-prepared to teach writing (contrary to mathematics and reading) (Cutler \& Graham, 2008; Philippakos \& Moore, 2017). Another reason is the prevalence of approaches that are attractive to teachers and instructionally feel "right" but are not effective or lack any evidence to suggest they are effective. Finally, the lack of professional development (PD) support after graduation with an overemphasis on $\mathrm{PD}$ in reading and mathematics that overshadows writing can be reasons for teachers' lack of implementation of effective practices (Troia \& Graham, 2016; Philippakos \& Moore, 2017).

The purpose of the current study was to examine the effects of a PD approach on genre-based strategy instruction that was conducted online and without any face-toface interaction between the researcher and teachers. The PD for the delivery of the evidence-based approach incorporated an online webinar, virtual teacher observations with distance coaching, and the provision of written feedback.

\section{Instructional approaches}

Writing is both a cognitive and a social task that takes place within a cognitive and a social space (Prior, 2006). As a cognitive task, writing performance can be constrained by writers' knowledge about cognitive processes such as planning, text generation, and evaluating to revise, by their long-term memory and knowledge about the topic, audience, genre, and their motivation as this relates to predispositions, beliefs, and attitudes. Writing, can be also influenced by the social environment and the audience that interacts with the author's words, the collaborators the writer has, and the writing medium (Graham, Harris, \& Chambers 2016 b; Hayes, 1996, 2004, 2006). 
Several instructional approaches have been found to support students' writing quality with writing strategy instruction leading to statistically significant effects on writing performance of elementary (Graham et al., 2012 a; Graham et al., 2016b), middle (Graham et al., 2016 a; Graham \& Perin, 2007a, 2007b), high school (Graham \& Perin, 2007a, 2007b), and postsecondary students (MacArthur, Philippakos, \& Ianetta, 2015). Strategy instruction supports the application of conscious processes for the completion of challenging cognitive tasks (Graham et al., 2016b; MacArthur, 2011). Students are taught how to plan, construct sentences, revise, and edit their work. Overall, they are systematically taught how to plan, draft, evaluate to revise, and edit their work using effective pedagogically sound methodologies such as think aloud modeling and collaborative practice.

Strategy instruction when combined with self-regulation further supports students' ability to manage the writing task and process (Graham, McKeown, Kiuhara, \& Harris, 2012b; Harris \& Graham, 2009). For instance, considering that writing is a problem-space, students develop goals that are specific to their performance and the writing task, and engage in reflection for the development of a new cycle of goals (Traga Philippakos, 2020). One of the most effective instructional approaches that has been found to yield positive effects across grade levels and contexts is the Self-Regulated Strategy Instruction model (SRSD; Graham \& Harris, 1989; Harris \& Graham, 2009) that consists of six instructional stages that promote mastery.

Genre-based strategy instruction builds on SRSD and its emphasis on goal setting and self-regulation (Harris \& Graham, 2009) and incorporates theories on genre (Martin \& Rose, 2012; Rose, 2016), reading and writing connections (Graham \& Hebert, 2010; Graham et al., 2018; Tierney \& Shanahan, 1991), evaluation for revision using genre-specific criteria (Philippakos, 2017; Philippakos \& MacArthur, 2016a, b), and connection between planning and revision using genre elements (Englert, Raphael, Anderson, Anthony, \& Stevens, 1991). The approach has been found to support learners' writing performance across genres in studies with primary and upper elementary students (Traga Philippakos, 2020; Traga Philippakos, 2019; Traga Philippakos \& MacArthur, 2020; Philippakos, MacArthur, \& Munsell, 2018; Philippakos, Overly, et al., 2018). Traga Philippakos (2019) conducted a study with 121 first graders and six classroom teachers who were randomly assigned to treatment and control in order to examine whether students who received instruction on genre-based strategy instruction wrote better quality procedural papers than their control peers. Students wrote procedural papers at pretest and posttest and treatment students were taught how to plan, draft, evaluate to revise, and edit their work through a gradual-release of responsibility approach and with systematic instruction of genre. Teachers of the treatment group participated in face-to-face workshops while coaching was via video observations. The results showed that students of the treatment group outperformed their peers at posttest and teachers shared positive comments on the use of videos for observations and coaching. Teachers favored written feedback as a way to receive coaching support. Similarly, in a study by Traga Philippakos \& MacArthur (2020), second grade students were taught how to write opinion papers using genre-based strategy instruction that incorporated collaborative reasoning and oral argumentation with genre-based strategy instruction. Students $(n=80)$ and teachers $(n=4)$ were randomly assigned to condition and 
instruction lasted for 10 days. Treatment students wrote papers of better quality and even though both groups of students included more reasons in their papers, students of the treatment group provided introductions and conclusions that acknowledged the audience. Teachers of the treatment group and of the control group videotaped their instruction daily and treatment teachers received written feedback immediately after the completion of their instruction.

\section{Professional development: elements of effectiveness}

Professional development is necessary for staff's continuous professional growth. Among scholars there is a consensus that for effective PD to take place, the following features are needed: (1) focus on content with tasks related and directly linked to that content, (2) active learning, so teachers and learners have opportunities to practice, receive feedback, reflect and actively be present in the learning experience, (3) coherence so tasks, practices, expectations connect and are not foreign to one another, (4) duration so learning is on-going as a "one-shot" approach cannot support implementation of effective practices, and (5) active participation in which members collaborate and come to develop an interactive learning community (Ball \& Cohen, 1999; Birman et al., 2000; Desimone, 2009; Garrett, Porter, Desimone, Birman, \& Yoon, 2001; Kennedy, 2016). The role of leadership is also essential (Desimone \& Garett, 2015; Guskey \& Huberman, 1995); The coherence in the message about the importance of the PD, the engagement that leadership and district members show as well as follow-up support for implementation are necessary for instructional change and effective PD outcomes (Tallerico, 2014; Traga Philippakos, under review). Further, effectiveness of PD should be determined through the implementation of evidence-based practices since it could be challenging to conclude whether failure of a PD model originated from the model or it is a consequence of a focus on an ineffective practice.

PD components usually include a model of direct instruction with theory, demonstration, practice, and follow-up coaching by experts (Joyce \& Showers, 2002; Showers, Joyce, \& Bennett, 1987). In initial workshops and lectures of direct instruction, teachers are introduced to theoretical principles related to a targeted approach, which is further explained and modeled before they have the opportunity to apply it and receive feedback on their application. Later, during implementation of the approach in their classrooms, teachers receive expert support and feedback. Coaching is an important component of PD as it refers to support provided by an expert to a learner on a targeted approach and is linked to positive change in instructional implementation (Neuman \& Cunningham, 2009; Reinke, Stormont, Herman, \& Newcomer, 2014) and to teachers' self-efficacy and satisfaction (Cornett \& Knight, 2009). Regarding PD on writing, several strides have been made (see the works of Festas et al., 2015; Harris, Graham, \& Atkins, 2015; Harris et al., 2012; McKeown et al., 2016). For instance, the work of Harris and colleagues on the application of the Self-Regulated Strategy Development model (SRSD) within a practice-based PD framework has shown positive effects on students' writing when provided in Tier 3 and Tier 2 settings. But there is a need for systematic analysis and 
examination of PD models in Tier I settings that lead to sustainability within school systems (McCarthy \& Geogeghan, 2016).

\section{Professional development: virtual alternatives to face to face formats}

Due to timing or distance constraints, web-based training without live interaction between learner and coach/consultant may occur. Such training can be cost effective as there are no costs related to travel or stay for the consultant (Newton \& Ellis, 2005); further, it can be more flexible on its timing as sessions can be scheduled when participants are available; finally, it can be efficient as larger groups of participants can receive the training but individuals can access content as needed. In web-based training formats, coaching is also provided virtually; Thus, learners receive support on their instructional implementation using tools that allow feedback (e.g., video conferencing). Studies on PD have examined the effects of virtual feedback and the effects of synchronous coaching on instruction with positive outcomes (Allen, Pianta, Gregory, Mikami, \& Lun, 2011; Shaha \& Ellsworth, 2013; Powell, Diamond, Burchinal, \& Koehler, 2010). Downer, Pianta, Fan, Hamre, Mashburn, \& Justice, (2011) conducted a study with 161 teachers that evaluated the effects of a web-based professional development approach called MyTeachingPartner (MTP) on 1338 students' language and literacy development. The results showed that teachers' supported by video-based consultation and web-based examples of teaching practices were more effective than just the provision of instructional resources. Further, studies that examined teachers' application of reading tasks via remote delivery of coaching with the inclusion of other technological innovations reveal the potential of online PD practices. For instance, Powel and colleagues (2010) conducted a study with 88 Head Start teachers and 759 children investigating the effects of remote versus on-site coaching on children's early-literacy skills without statistically significant effects favoring one or the other approach. Recently, Traga Philippakos (2020) conducted a yearlong PD on writing that included workshops, on-site coaching, and virtual coaching of classroom teachers in grades three to five. Teachers were supported to teach in whole-group, Tier I format, the genres of story, persuasion, and compare -contrast and differentiate in small groups based on students' needs through conferencing. Data were collected across the year and across all genres. The results showed that students' writing improved for the genres they were taught and continued to improve across the year. Teachers' confidence increased and teachers provided positive comments on the workshops, on the modeling by the researcher, on the coaching, and on the provision of written feedback that followed immediately after teachers' instruction. Coaching in this work was both through videos and live teacher-researcher interactions.

Virtual PD with coaching has not been examined extensively in writing PD models. In the studies by Traga Philippakos (2019, 2020), and Traga Philippakos \&MacArthur (2020), virtual coaching was included without the entire PD offered online. Considering the cost for PD that districts and schools are asked to endure as well as unexpected circumstances that can interrupt the "normal" operation of 
schooling (e.g., COVID-19), the provision of virtual coaching and virtual PD can further support implementation of evidence-based practices in literacy in general (Roth et al., 2011; Taylor, Roth, Wilson, Shuhlatz, \& Tipton, 2017) and in writing in particular.

\section{Theory of change}

Often, approaches to PD attempt to change teachers' beliefs and attitudes with the expectation that such changes will support change on teachers' practice; however, according to Guskey (2002), changes on teachers' instructional practices can lead to change on their beliefs when their practices lead to observable changes on their students' performance. Thus, the theory of change in this study is that online writing PD with virtual workshops, coaching, and feedback supports teachers' fidelity of implementation (practice) and that effective implementation of evidence-based practices leads to increased student-writing achievement. When teaches are supported in implementation of instruction with fidelity, observed changes are the result of the intervention (Gresham, 1989), while high-teacher fidelity can connect to student performance (Furtak et al., 2008).

Therefore, a reciprocity in the relationship of teacher-student outcomes is expected. As teachers implement the lessons with fidelity, their belief in the approach and their self-efficacy increases when they see the effects on their students' performance. Students' increased outcomes then lead to higher teacher outcomes. Since strategy instruction is an instructional approach with several components, teachers need to be supported in their practice to effectively develop pedagogical content knowledge. Successful performance on a task has the strongest effects on a learner's self-efficacy (Bandura, 1999; Hidi \& Boscolo, 2006). Teachers' increasing knowledge about writing instruction and effects on students can enhance teachers' self-efficacy (Graham, Harris, Fink, \& MacArthur, 2001). Thus, it is anticipated that teachers' increased fidelity will lead to increases in their belief on the value of the instructional approach and on their confidence.

The current study assesses fidelity of implementation and teacher feedback about the PD; it then assesses student writing achievement as additional evidence of effective implementation.

Teachers' instructional delivery would be determined by their understanding of the instructional approach; thus, the model incorporates workshops with theory explanation, modeling of instruction, and evaluation. Teachers' confidence would be affected by their belief that their instruction supports students and their understanding about procedural writing; thus, coaching support would need to be immediate for them to be able to apply the feedback in their instruction and improve their instructional delivery and virtual coaching provides this affordance. 


\section{Current investigation}

This work expands the previous study with first graders (Traga Philippakos, 2019) to include second graders and the PD format with third to fifth graders (Traga Philippakos, 2020) to provide the PD support for instructional delivery fully virtually and without any face-to-face interactions between the researcher and teachers. Research has established that strategy instruction with self-regulation is effective (e.g., McKeown et al., 2019), but more studies are needed on PD. The goal of this project was to determine whether a fully online PD could support teachers in implementing strategy instruction with high fidelity. Thus, the focus was on second graders and on procedural writing as this is a type of informative writing that students are expected to complete based on the standards; it is also a genre that is prominent in science.

The research questions in this investigation were:

- Does this PD model support teachers' fidelity of implementation and confidence?

- Do teachers find the model to be feasible, and what is their feedback?

- Do treatment students produce papers of better quality than the controls at posttest, transfer, maintenance tasks and have higher level of confidence compared to controls?

- Are treatment students better able to explain the purpose of the genre, its elements, and the writing process compared to control?

- Do treatment students perform better than controls on standardized writing measures?

- Do treatment and control students perform equally after control teachers learn and practice the approach and treatment students collaboratively practice with controls?

\section{Methods}

\section{Participants and setting}

The study was conducted in a rural, public school located in the East Coast of the United States. The school serves a total of 762 students $(n=366$ female, PreKindergarten to Grade 5) and receives Title I funds (information provided from https ://nces.ed.gov/ccd/schoolsearch/). For this study, participants were 84 students who were blocked by disability and Limited English Proficiency and randomly assigned to the experimental and control condition $(n=42 ; 23$ female). Table 1 presents students' demographics and academic performance.

Teacher participants were four teachers who were blocked in pairs by years of experience and education and randomly assigned to condition. All teachers had degrees in childhood education with one of the treatment teachers receiving a Master's degree in Early Childhood education and one of the control teachers receiving a Masters in elementary education and a doctorate in Early Childhood Education. 
Table 1 Demographic and Academic Information by Group

\begin{tabular}{|c|c|c|c|}
\hline & Treatment $n=42(50 \%)$ & Control $n=42(50 \%)$ & Total $n=84(100 \%)$ \\
\hline Female & $22(54.8)$ & $23(52.4)$ & 45 (53.6) \\
\hline Male & $20(45.2)$ & $19(47.6)$ & $39(46.4)$ \\
\hline White & $31(73.8)$ & $30(71.4)$ & $61(72.6)$ \\
\hline African American & $7(16.7)$ & $6(14.3)$ & $13(15.5)$ \\
\hline Latino & $3(50)$ & $3(50)$ & $6(7.1)$ \\
\hline Other & $1(2.4)$ & $3(7.1)$ & $4(4.8)$ \\
\hline IEP & $3(50)$ & $3(50)$ & $6(7.1)$ \\
\hline ESOL & $5(50)$ & $5(50)$ & $10(11.9)$ \\
\hline Winter $\mathrm{ORF}^{\mathrm{a}} \mathrm{M}(\mathrm{SD})$ & $82.44(34.42)$ & $83.50(37.43)$ & \\
\hline
\end{tabular}

${ }^{a}$ Oral Reading Fluency (Dynamic Indicators of Basic Early Literacy Skills, 2012), correct words per minute (CWPM). Scores $>71$ indicate low risk

Teachers and students were invited via informed consent and students individually completed assents.

The researcher was approached by the curriculum coordinator to visit the school and provide professional development on writing and reading. The researcher, the curriculum coordinator, and the principal discussed the possibility for a research project. The researcher explained the components of the study, her responsibilities, and the procedural needs for a virtual PD. The school agreed, and a research study was initiated under the condition that the researcher would provide PD at the completion of the study to all teachers across grades $\mathrm{K}$ to 5 .

\section{Experimental design and study timeline}

The study employed a pretest-posttest control group design. The intervention lasted for ten instructional days and all study-related tasks (excluding the intervention) were completed in 14 days. Specifically, prior to the beginning of the intervention, students responded to two procedural topics (in two consecutive days) and standardized measures were collected (across 2 days). After the intervention, students wrote in response to two procedural prompts in two consecutive days and also completed the standardized measures. Two days after the intervention, a transfer task was completed on a science topic that asked students to read information about an animal, and using information from a visual representation of its life cycle write how the animal developed. No reminders were provided to students that this was a procedural type of writing. The next day students were asked to complete a science task with a reminder. One day later, students also completed a transfer task on persuasive writing that was not taught. The decision to do this was based on previous research findings that showed that students transferred information from persuasive to procedural (Traga Philippakos, 2020; Traga Philippakos, Robinson, \& Munsell, 2018) and the goal was to examine whether such a transfer was possible. Three weeks after the intervention, two maintenance tasks were collected in two consecutive days. Then control teachers received PD, were introduced to the genre, and modeled its 
completion in class. At the collaborative writing stage, treatment students acted as facilitators and supports for the use of the strategies to control students. Finally, all students completed a last writing task on procedural writing.

\section{Initial student group comparisons}

Multivariate Analysis of Variance (MANOVA; Berger, Maurer \& Celli, 2018; Field, 2009) was conducted for students' performance on Dynamic Indicators of Basic Early Literacy Skills (DIBELS; Good \& Kaminski, 2002) Oral Reading Fluency (DORF), on performance on sentence construction using the Test of Written Language (TOWL-4, 2014; Hammill \& Larsen, 2009) on story writing using the Test of Early Written Language (TEWL-4; Hresko, Herron, Peak, \& Hicks, 2012), on sentence combining using the Wechsler Individual Achievement Test (WIAT-3; Psychological Corporation, 2009) and on story writing on Oral Written language Skills (OWLS-3; Carrow-Woolfolk, 2011). There was no statistically significant difference between conditions on any of the measures ( $p$ values $>.36$ ). Further, no statistically significant differences were found for gender, ethnicity, language proficiency, and disability between the two groups.

\section{Instructional tasks}

Both groups of teachers taught procedural writing. Teachers in the control condition taught using a structured writing program the school adopted for grades $\mathrm{K}$ to 5 the previous year. All teachers had a manual and its resources (e.g., graphic organizers) in their classrooms. All teachers had received professional development on the use of this resource prior to this research project and were coached by their curriculum coordinator. According to its lessons, teachers explained to students the writing purposes, provided examples of the writing tasks by modeling components of it while students practiced applying those in their writing. Teachers conducted mini-lessons and conferences and students practiced writing their papers while they made revisions through teacher-student conferences.

Teachers in the treatment condition taught using principles of genre-based strategy instruction that incorporated strategy instruction and dramatization (Traga Philippakos, 2019). Dramatization was used at the stages of modeling and evaluation to better support students develop ideas and later at the evaluation stage to identify gaps in the information provided to the reader (e.g., incorrect steps or missing steps). Specifically, at the planning stage teachers thought out loud and dramatized or mimed the completion of a process. As teachers pretended to complete the task, they considered the materials, the order of steps as well as the accuracy of those. This was decided in order to allow students to verbalize and mime the steps they would follow so they could develop ideas and correctly identify the order of steps. At the evaluation stage, the teacher dramatized the actual steps by following the process that was written in the paper. At this stage the emphasis was on the clarity of 
the information for the reader and for students to learn to critically review and revise areas that were unclear.

Further, the approach emphasized the use of oral language and teachers modeled and later engaged students in saying their sentences prior to drafting them using sentence frames to structure their work. When students used the ideas from the graphic organizer (GO) and tried to provide sentences, teachers told students to "say it, hear it, write it, reread it, fix it if you need it" (Philippakos \& MacArthur, 2020). Across the instructional weeks, teachers modeled how to set goals for specific writing tasks, how to manage time and their behaviors to effectively complete a task by progress monitoring their work and by reflecting on their strategy use.

Also, the approach emphasized the rhetorical analysis of topics that were assigned for reading and writing. Students were taught to carefully consider the Form of writing they read or wrote about, the Topic and Title, the Audience, the Author and their perspective or readers' bias, the writing purpose (Philippakos, 2018).

The overall instructional sequence is based on a Strategy for Teaching Strategies (STS, Philippakos, MacArthur \& Coker, 2015; Philippakos \& MacArthur, 2020) and promotes gradual release of responsibility (Graham et al., 2012a) as it draws from the model of self-regulated strategy instruction (Harris \& Graham, 2009), which supports students to develop independence. The lessons within STS are: (1) Introduction to the writing purposes: Students are provided with information about the writing purposes, the specific genre, its application in school and in real life, its organizational elements, syntactic characteristics, and linguistic/vocabulary features and words; (2) Introduction of genre via read-alouds: Teachers conduct a read aloud on a paper/book/writing of this genre, point out the syntactic and linguistic/vocabulary features (e.g., In addition, ; Next, ___ ), take notes using a graphic organizer with the elements of the genre, and summarize the information using the notes from the graphic organizer; (3) Evaluation of good and weak examples: Teachers present and explain an evaluation rubric that includes the same elements as the genre and the graphic organizer that was used earlier for note taking. Teachers explain additional evaluation criteria that relate to the genre's syntax and linguistic characteristics as well as general writing expectations (e.g., inclusion of title if requested); (4) Think-aloud modeling: Teachers explain they will think out loud as they complete the writing process and use the resources to plan, draft, evaluate to revise and edit their work. As they think out loud they ask questions that relate to the specific step of the writing process they are completing and its components, their progress toward their goal, and their use of strategies, and they make comments regarding their state of mind and evaluation of their performance (e.g., I think I did well with the generation of ideas); (5) A focus on Self-regulation and a mini-lesson: Teachers revisit the comments they made at modeling and discuss with students how they can monitor their goal completion, their progress and use of strategies, and keep themselves engaged and positive even when tasks become challenging. As a group they review teachers' comments and develop statements they could use when they work. Teachers provide a mini-lesson on a specific genre-feature (e.g., steps and explanations in order or elaborate explanations); (6) Collaborative practice; 
Teachers and students work together to complete a new paper; (7) Guided practice; Students begin working on their own; (8) Preparation for peer review, selfevaluation, and peer review: Teachers model how to give feedback and students practice the process of giving feedback on papers written by unknown others. Students self-evaluate their papers to set new learning and writing goals, peer review, and determine their revisions. (9) Editing for Spelling, Capitalization, Indentation, Punctuation, and Sentences (SCIPS): Teachers model how to correct a specific, sentence-level issue that is prominent on students' writing (e.g., run-ons). Teachers model the correction, students practice in papers written by unknown others, they correct their papers and set editing goals. (10) Continuous practice to mastery and independence: Students write a new paper using their new goals. Lessons lasted for 2 weeks. More than one lesson was completed in one session/class meeting.

\section{Professional development approach}

The PD was done virtually without the presence of the researcher and included the use of workshop, videos of instruction, and coaching. The steps of the PD support were the following: First, treatment teachers watched a podcast that explained how writing is a cognitive and social process, explained findings on novice and experienced writers regarding the writing process, reviewed research on planning and revision, the recommendations of the elementary practice guide (Graham et al., 2012a), the Common Core State Standards guidelines for K to 5 with an emphasis for grade 2, and the specific instructional components and principles for this current project. Then, teachers were asked to watch videos as samples of the instructional approach and were provided with a manual that included lessons that addressed STS and its components. The edited videos addressed the lessons from the manual and were taught by the researcher and exemplar teachers. The videos included the following lessons of the STS: Lesson 1 and 2 (duration of $15 \mathrm{~min}$ ), Lesson 3 (duration of $15 \mathrm{~min}$ ), Lesson 4 (duration of $20 \mathrm{~min}$ ).

When the study began, teachers were coached by the researcher so they would apply the approach with fidelity. Teachers video recorded their lessons using their iPads, uploaded them to their Drive and shared them with the researcher, who watched them, and provided written feedback to each teacher via email. When teachers needed clarifications on comments, they would email the researcher and set up individual phone conferences to discuss questions. Each of the treatment teachers spoke on the phone with the researcher for 10-15 min each time across three instructional days. The time was utilized for teachers to share any questions about the content of the written feedback, reiterate their understanding about the feedback, and seek clarifications to comments. 


\section{Measures}

\section{Professional development model}

In order to evaluate the clarity of the model's components, a questionnaire was developed that asked teachers to explain information they learned during the podcast. Teachers were also asked to rate the parts of the podcast.

\section{Observations}

Observations were completed with all participating teachers, who were observed at least three times. Observations of the treatment teachers were conducted to examine the fidelity of lesson implementation. Control teachers were observed to describe their instruction and to examine whether there were instructional commonalities.

\section{Fidelity of lesson implementation}

In order to examine whether treatment teachers taught lessons as intended, a checklist was developed that addressed each lesson's component. A rater watched videos of lessons on introduction to the genre and summarization, evaluation of good and weak papers, and of modeling to examine whether teachers delivered the lessons as developed. A second rater also watched videos by the two treatment teachers. Intra-class correlation coefficients (ICC) were used as reliability estimates (poor ICC $<.40$; fair ICC $=.40$ to .59 ; good $\mathrm{ICC}=.60$ to .74 ; excellent $\mathrm{ICC}=.75$ to 1.0 ) (Hallgren, 2012). A two-way mixed model was used and Interscorer agreement was excellent $(\mathrm{ICC}=.98$ for introduction; $\mathrm{ICC}=.95$ for evaluation; $\mathrm{ICC}=.93$ for modeling).

\section{Teacher questionnaire}

Teachers were asked to complete a pretest (46 total items) and a posttest questionnaire (23 items). The pretest questionnaire asked teachers about their writing practices, their previous experience with PD on writing, and their level of preparation to teach writing. The posttest questionnaires asked them to share their experience and provide comments about future PD work and needs they had.

\section{Teacher confidence}

Teachers rated their level of confidence on teaching writing on a scale from $1=n o t$ at all confident, to $6=$ very confident (Graham et al., 2001; alpha $=.93$ ).

\section{Essay-writing tasks}

Students completed two pretest procedural papers, two posttest procedural papers, two transfer papers on science topics, another transfer paper on a persuasive topic, 
two maintenance tasks after 3 weeks of instruction, and a final procedural paper after all students (control and treatment) observed their teachers explain the writing tasks and model how to respond. Students of the control engaged with treatment students in collaborative writing in which the treatment students explained to control how to write. All assessments were administered by research personnel, and students completed them within $40 \mathrm{~min}$ in their homerooms. To increase reliability, multiple pretest, posttest, transfer and maintenance essays were collected (Schoonen, 2005). Students' papers were typed by undergraduate students unfamiliar with the design of the study. A different undergraduate student reviewed the typed work to confirm accuracy. Essays were evaluated for quality by graduate students unfamiliar with the design of the study. Raters were trained by the first researcher using the rubrics mentioned below and anchor papers. All papers were rated independently by two raters who were blind to the sequence of measure administration.

\section{Procedural papers' quality}

Writing quality of procedural papers was measured using a 6-point holistic rubric that examined ideas, organization and word choice (Traga Philippakos, 2019; Traga Philippakos, Robinson \& Munsell, 2018). Participants were asked to rate each paper by examining the ideas and their clarity, the organization of the paper and whether it adhered to the genre expectations, and the word choice and whether it was descriptive and also accurate for the genre. Raters were asked to provide an overall score that considered these criteria. Interscorer agreement was excellent $(\mathrm{ICC}=.95)$.

\section{Persuasive papers' quality}

The quality of persuasive papers was measured using a 6-point holistic rubric that addressed ideas, organization and word choice (Philippakos, MacArthur \& Munsell, 2018). The rubric was specific to persuasive writing-organizational expectations and work choice. Interscorer agreement was excellent $(\mathrm{ICC}=.94)$.

\section{Science papers' quality}

The papers were scored using a 6-point rubric that addressed ideas and their accuracy, organization, and word choice. Even though the rubric's expectations on organization and work choice was similar to the previous rubric on procedural writing, it also included the criterion of accuracy on the presented ideas (and whether students had plagiarized information or not). Interscorer agreement was excellent $(\mathrm{ICC}=.92)$. 


\section{TOWL-4}

In order to examine whether there were changes to students' sentence writing as a result of instruction, the sentence-writing task of the Test of Written Language - Fourth Edition was completed (Hammill \& Larsen, 2009). Interscorer agreement was excellent $(\mathrm{ICC}=.92)$.

\section{TEWL-4}

The story writing task of the Test of Early Written Language-Third Edition was also completed (Hresko et al., 2012. Interscorer agreement was excellent $(\mathrm{ICC}=.80)$.

\section{OWLS-3}

The procedural writing task of the Oral and Written Language Skills (CarrowWoolfolk, 2011) measure was also used at pretest to control for students' writing ability. Interscorer agreement was excellent $(\mathrm{ICC}=.79)$.

\section{WIAT-III}

The sentence combining and the sentence building tasks of The Wechsler Individual Achievement Test-Third Edition (WIAT-III; Wechsler, 2009) were also completed to control for students' sentence-level skills at pretest. Interscorer agreement was excellent $(\mathrm{ICC}=.91)$.

\section{Student confidence scale}

Students were asked to complete a questionnaire that asked them to report their confidence percentage for completing specific writing tasks that related to skills and processes for procedural writing (e.g., writing a procedural paper with clear steps). The items were based on previous work (Pajares, 1996; Traga Philippakos, 2019). Confidence percentage was rated on a scale from $0=$ not at all confident to $100=$ very confident . Practice tasks were completed ahead of time and then each item was read to students out loud. Next, each student selected the number that represented her/his confidence.

\section{Teacher interviews}

Phone interviews with all teachers were conducted at pretest and posttest (each for 30-40 min). Initial interviews were conducted to better understand teachers' writing practices and PD opportunities as well as challenges and concerns about instructional procedures and students' needs. Interviews conducted at posttest 
strived to capture teachers' impressions about their instruction and students' writing performance after they received instruction. Teachers of the treatment group were also asked to provide their feedback about the PD approach, the coaching process, the instruction, and share suggestions for revisions. Structured interview protocols were used with common questions for all with follow-up questions for clarification of responses (e.g., tell me more about

\section{Student interviews}

Control and treatment students were also interviewed at posttest $(n=10$ students per condition). Student selection was based on their performance at DORF and a sample of students who performed at, above, and below benchmark were randomly selected from the control and treatment groups. A structured protocol was used that asked students to explain the purpose of procedural writing, the writing process, ways to revise their work, and challenges they faced with this type of writing. Interview time ranged from 5 to $10 \mathrm{~min}$ per student.

\section{Interviews}

Since a structured protocol was used with students and teachers, the data were read by question to first identify codes and then proceed with themes for analysis (Strauss $\&$ Corbin, 1990). For example, students were asked to explain how writers plan procedural papers. Responses for treatment students were specific to the instruction (e.g., FTAAP, Brainstorm, Graphic Organizer (GO); some of the components; none of the components) and for control students were "think in my head," "use a GO," "make a list." The first author developed the codes and the two authors examined agreement and made modifications as needed. The same process was followed for the teacher and student interviews. For the student interviews only, since we had 20 students, we independently coded four interviews with overall agreement of $91 \%$. The second author applied the codes and summarized the findings for the questions.

\section{Results}

\section{Professional development results}

\section{Professional development model}

Overall, treatment teachers rated the podcast, the follow-up questions on its content, the use of the manual, and the videos as very effective and extremely effective $(M=4.5$ on a 5-point scale across each item). Teachers shared in their responses that videos helped them better understand the process to teach and understand the manual's information while the questions about the podcast were connected with the content of what they had watched and this helped them better reflect and think about that information (e.g., theory, development, research findings). 
Control teachers, who completed the workshop after the collection of maintenance tasks, also provided high ratings to the podcast and the components of the workshop $(M=5.00)$. Overall, teachers in both conditions positively commented on their ability to discuss with the researcher after the completion of the podcast about any questions they had. They all also commented positively on the clarity of the manual and on the use of videos that "brought the instruction to life."

\section{Fidelity of lesson implementation}

Fidelity of lesson implementation for treatment teachers was high at $96 \%$ and $94 \%$.

\section{Teacher results}

\section{Teacher interviews: pretest}

Regarding the approaches used to teach writing, teachers shared that their school provided a structured program for reading that engaged students in written responses while they also used a published writing program. They shared that they also used resources from Units of Study (Calkins, 2006) and included mnemonics such as RACE (restate, answer, cite, evidence/example) to support students' written responses. Teachers provided instruction in genre-based writing and embedded grammar instruction by modeling with whole-group instruction followed by small-group conferencing based on shared student needs. Writing was taught using Write Steps or other supplementary websites like Teacher Pay Teachers or a culmination of past experiences (Units of Study) while constructed responses came from the reading curriculum. According to the Write Steps program, teachers model mini-lessons to introduce concepts, conference with students individually or in small groups to provide support as needed, and students navigate through the writing process from planning to publishing and sharing. Teachers shared they used modeling with strong and weak examples and conferencing with individuals or small groups during writing instruction. Teachers expressed concerns about the amount of time devoted to the teaching of writing and shared their concerns about their students' spelling, reading skills, challenges to use punctuation correctly, generation of ideas, and writing stamina to expand their ideas. Teachers shared they were somewhat prepared to teach writing due to the experience they have accumulated across time. All but one shared they were ill-prepared by their colleges to teach writing. Teachers also explained they were not provided with frequent PD but felt prepared to teach writing because of the resources they were provided and the support of their reading coordinator. Consensus among all teachers was a desire to have more PDs and more time to plan their writing instruction. 


\section{Teacher interviews: posttest}

Interviews of teachers were analyzed by condition in order to further examine teachers' overall views about their instruction and its effects on students. For treatment teachers, information was also collected on their thoughts about the effects of PD and intervention and possible revisions the developers could make.

\section{Confidence in teaching writing: control}

Teachers expressed their confidence to teach writing as a result of their years of experience and as a result of available resources. As one of the teachers said, "I am confident to teach anything as long as the resources are provided."

\section{Treatment}

Both treatment teachers claimed their confidence was bolstered because of learning how to implement the approach and all of the elements and components needed to write a strong procedural essay. One teacher shared,

Now I do feel more confident because I know the elements that are needed for a good procedural writing and I would be able to teach it in a way that students memorize the elements - I feel like that was a piece that I was missing when I was teaching was the student accountability for the memorization of the elements - now I understand what needs to be taught and how but at the same time you can keep the students more accountable in a way.

\section{What worked well instructionally: control}

In general, teachers explained that students generally learned the concepts related to procedural writing and expressed surprise about the lack of behavior issues which was a concern they had due to the random assignment of students. Teachers also shared that even though students learned tasks (e.g., use of a checklist for editing), they needed far more practice to be able to apply it correctly.

\section{What was challenging: control}

Teachers explained that it was their intention to use the writing program their school provided but they also used resources from Teachers Pay Teachers, Pinterest, or from other websites. Teachers, as mentioned at pretest, also commented on challenges related to students' background knowledge. Not all students had information about topics, and they were challenged in their responses. Teachers also shared the need to have proper training in writing and incorporate reading with writing. 


\section{What worked well instructionally: treatment}

Teachers commented positively on the use of resources and instructional sequence. The introduction of the ladder was an essential part of the lessons as one teacher explained, "I think them seeing it as a process that they can go up and down worked well for them." Additionally, students were responsible for knowing the elements and including them in their paper which increased students' independence and selfregulation when writing. All materials were helpful including the posters, adding an agenda, lessons in a manual, and videos. Finally, the peer review process was an important part of the lessons and facilitated accountability for the students. As one of the teachers explained,

[students] were actually becoming the evaluator so they took more accountability for their writing because they knew someone was reviewing their writing and it was one of their peers - they scored their own writing with the rubric and they took their writing a step further and that they were evaluating their writing and that was something that was missing before - when I taught writing in the past it was simply I was the evaluator - now it was like they were using their rubric and looking at each part and each piece and giving themselves a score of clarity which is important as a writer and so I think those are key pieces that I was missing and that really worked well.

Teachers shared that students responded well to the intervention and overall their learning improved. They also said that students increased their writing skills and they improved by setting goals through evaluation to revise. Students increased their skills related to procedural writing which was evidenced by including the elements in their papers and stating the elements accurately during quizzes. One of the teachers shared that the rigor of the approach was such that she thought it would not work for students. As she said,

When we started because I was overwhelmed this ain't gonna work the kids aren't going to get this I did feel that way just because I was overwhelmed pretty much but I have trusted you and I knew something was going to come out of this positive. I think after seeing the end results papers like I told [principal] today, it is unreal what they can do to me. I mean we have not even been doing it that long. Think about if we like they had more practice with this what the end result would be.

Students not only improved the quality of their writing, but also increased their quantity of writing, as well as their stamina and endurance for writing based on teachers' comments.

\section{Feedback for remote professional development and coaching: treatment}

Teachers shared that videos serving as instructional models and timely and detailed feedback were helpful during the PD coaching sessions. Even though the PD and coaching were provided remotely, the teachers stated they understood the approach 
and as they engaged in learning and watching videos of instruction as well as applying the tasks, they became comfortable teaching. They also shared that completing videos of lessons and uploading daily to receive feedback was less stressful to them than it would have been to have someone physically present in the room during coaching sessions. Teachers gave positive comments on the use of written feedback that was immediate and allowed them to better understand how to address challenges and implement the lessons with fidelity.

\section{Suggestions for PD improvements}

Teachers were positive in their comments on the PD and all its components. Regarding the introductory workshop, one teacher suggested to provide opportunities to work on 2 days (day 1: theory with research and explanation of approach and day 2: Video PD sessions). Treatment teachers showed a preference for videos over the explanation of the theory and components of instruction (e.g., STS) and asked for more videos.

\section{Teacher confidence}

Descriptive analysis of responses to the confidence scale $(\alpha=.80)$ showed that control teachers' mean confidence at pretest was high $(M=5.35, S D=.49)$ and treatment teachers' confidence ranged from slightly to moderately confident $(M=4.65$, $S D=.91)$. At posttest control teacher's confidence remained high $(M=5.05$, $S D=.21)$ and treatment teachers' also increased in their confidence $(M=5.30$, $S D=.42)$.

Table 2 Quality at pretest, posttest, maintenance, transfer, and after collaboration

\begin{tabular}{lll}
\hline & Treatment M (SD) & Control M (SD) \\
\hline Pretest 1 & $2.93^{\mathrm{a}}(1.36)$ & $3.05^{\mathrm{a}}(1.25)$ \\
Pretest 2 & $3.00^{\mathrm{a}}(1.21)$ & $2.75^{\mathrm{a}}(1.11)$ \\
Posttest 1 & $4.39^{\mathrm{a}}(1.00)$ & $3.20^{\mathrm{b}}(1.14)$ \\
Posttest 2 & $4.26^{\mathrm{a}}(1.35)$ & $3.33^{\mathrm{b}}(.95)$ \\
Transfer persuasion & $3.65^{\mathrm{a}}(1.09)$ & $\left.3.32^{\mathrm{a}}(.96)\right)$ \\
Transfer science no reminders & $3.29^{\mathrm{a}}(1.37)$ & $2.97^{\mathrm{a}}(1.12)$ \\
Transfer science with reminder & $3.15^{\mathrm{a}}(1.37)$ & $2.81^{\mathrm{a}}(1.13)$ \\
Maintenance & $3.57^{\mathrm{a}}(1.50)$ & $3.00^{\mathrm{b}}(1.06)$ \\
Maintenance & $3.61^{\mathrm{a}}(1.50)$ & $2.64^{\mathrm{b}}(1.08)$ \\
After collaboration & $4.25^{\mathrm{a}}(1.47)$ & $3.36^{\mathrm{b}}(1.45)$ \\
\hline
\end{tabular}

$M$ Mean, SD standard deviation

${ }^{\mathrm{a}, \mathrm{b}}$ Values with different superscripts are different at $p<.01$. Results are based on pairwise comparisons 


\section{Student results}

\section{Writing quality: posttest}

In order to examine the effects of condition on immediate writing tasks, a MANCOVA was conducted with two dependent variables (quality of both posttests), eight covariates (quality of each pretest, TOWL-4, WIAT sentence building and sentence combining, OWL-III, TEWL, and DORF), and one between-group factor (condition; Stevens, 2002; Weinfurt, 1995), (see Table 2). A statistically significant Box's test (Box's $M=14.98, F(3,1,250,020.35)=4.86, p=.002)$ indicated unequal variance-covariance matrices of the dependent variables between the two groups; therefore, Pillai's trace, which is robust to violations, was used in assessing the multivariate effect (Stevens, 2002). The analysis found that three covariates were statistically significant: The pretests (Pillai's trace $=.08, F(2,76)=3.20, p=.05, \eta^{2}=.08$; and Pillai's trace $=.17, F(2,76)=7.49, p=.001, \eta^{2}=.17$ ) and TEWL (Pillai's trace $=.18$, $\left.F(2,76)=8.50, p<.001, \eta^{2}=.18\right)$. The analysis was rerun with those included.

A statistically significant effect was found for condition (Pillai's trace $=.31, F$ $(2,76)=16.97, p<.001$, partial $\left.\eta^{2}=.31\right)$. Follow-up univariate tests found an effect of condition on both posttests $\left(F(1,81)=30.56, p<.001\right.$, partial $\eta^{2}=.30$ and $(F$ $(1,81)=13.77, p<.001$, partial $\left.\eta^{2}=.14\right)$. Pairwise comparisons with the Bonferroni correction showed that students in the treatment condition wrote papers of better quality $(p<.001)$.

\section{Writing quality: transfer to science (no reminders)}

In order to examine the effects of condition on a science transfer task, an ANCOVA was conducted with one dependent variable (quality of science), eight covariates (quality of each pretest, TOWL-4, WIAT sentence building and sentence combining, OWL-III, TEWL, and DORF), and one fixed-factor (condition; Field, 2009) (see Table 2). All assumptions were examined and met. No statistically significant difference was found on the effects of condition $(p=.44)$.

\section{Writing quality: transfer to science (with reminders)}

Similarly, an ANCOVA was conducted for the transfer with reminders task using one dependent variable (quality of science), eight covariates (quality of each pretest, TOWL-4, WIAT sentence building and sentence combining, OWL-III, TEWL, and DORF), and one fixed-factor (condition) (Field, 2009). No statistically significant difference was found on the effects of condition $(p=.48$; see Table 2$)$. 


\section{Writing quality: transfer to persuasion}

An ANCOVA was also conducted for the transfer task on persuasive writing using as covariates quality of each pretest, TOWL-4, WIAT sentence building and sentence combining, OWL-III, and TEWL. No statistically significant difference was found on the effects of condition ( $p=.14$; see Table 2).

\section{Writing quality: maintenance}

A MANCOVA was conducted with two dependent variables (quality of maintenance tasks), and eight covariates (quality of each pretest, TOWL-4, WIAT sentence building and sentence combining, OWL-III, TEWL), and one between-group factor (condition) (see Table 2). Assumptions were examined and met (Box's $\mathrm{M}=7.48, F$ (3, $1,250,020.35)=2.41, p=.06$; Tabachnick \& Fidell, 2007). The analysis found that TEWL was statistically significant (Wilk's $\Lambda=.70, F(2,78)=16.37, p<.001$, partial $\left.\eta^{2}=.30\right)$.

A statistically significant effect was found for condition (Wilk's $\Lambda=.87, F(2$, $78)=5.87, p=.004$, partial $\left.\eta^{2}=.12\right)$. Follow-up tests found an effect of condition on one of the maintenance tasks $\left(F(1,81)=14.70, p=.001\right.$, partial $\eta^{2}=.13$ and marginally reached significance on the other $\left(F(1,81)=3.84, p=.053\right.$, partial $\left.\eta^{2}=.05\right)$. Pairwise comparisons with the Bonferroni correction showed that students in the treatment condition wrote papers of better quality at maintenance $(p=.001)$.

\section{Quality: peer instruction}

An ANCOVA was conducted with quality of writing as dependent variable and eight covariates (quality of each pretest, TOWL-4, WIAT sentence building and sentence combining, OWL-III, TEWL) and one fixed- factor (condition; see Table 2). Assumptions were examined and met (Field, 2009). There was a statistically significant effect of condition $\left(F(1,72)=14.46, p<.001\right.$, partial $\left.\eta^{2}=.17\right)$ and planned

Table 3 Pretest and posttest results for standardized measures

\begin{tabular}{lcc}
\hline & Treatment M (SD) & Control M (SD) \\
\hline Pre_TEWL & $26.80^{\mathrm{a}}(8.90)$ & $26.08^{\mathrm{a}}(7.56)$ \\
Post TEWL & $23.43^{\mathrm{a}}(6.92)$ & $23.50^{\mathrm{a}}(6.16)$ \\
PRE Sentence Combining_TOWL & $4.12^{\mathrm{a}}(4.81)$ & $3.45^{\mathrm{a}}(2.95)$ \\
Pre_WIAT Sentence Combining & $5.67^{\mathrm{a}}(8.84)$ & $4.75^{\mathrm{a}}(5.67)$ \\
Pre_Sentence_Building & $8.93^{\mathrm{a}}(6.47)$ & $7.76^{\mathrm{a}}(5.66)$ \\
PreOWL & $2.43^{\mathrm{a}}(5.48)$ & $2.31^{\mathrm{a}}(.64)$ \\
Winter DORF & $82.44^{\mathrm{a}}(34.42)$ & $83.50^{\mathrm{a}}(37.43)$ \\
Spring DORF & $107.98^{\mathrm{a}}(40.60)$ & $105.02^{\mathrm{a}}(43.49)$ \\
\hline
\end{tabular}

$M$ Mean, SD standard deviation

${ }^{\mathrm{a}, \mathrm{b}}$ Values with different superscripts are different at $p<.001$. Results are based on pairwise comparisons 
Table 4 Factor scores from pre to post

\begin{tabular}{lll}
\hline & Treatment M (SD) & Control M (SD) \\
\hline Pre affect & $75.48^{\mathrm{a}}(30.95)$ & $66.82^{\mathrm{a}}(27.7)$ \\
Post affect & $74.00^{\mathrm{a}}(31.82)$ & $70.65^{\mathrm{a}}(30.21)$ \\
Pre organization & $76.59^{\mathrm{a}}(19.91)$ & $75.65(18.27)$ \\
Post organization & $75.52^{\mathrm{a}}(16.42)$ & $70.39^{\mathrm{a}}(18.15)$ \\
Pre processes & $82.73^{\mathrm{a}}(14.48)$ & $78.34^{\mathrm{a}}(14.50)$ \\
Post processes & $83.29^{\mathrm{a}}(12.71)$ & $84.63^{\mathrm{a}}(15.00$ \\
Pre grammar & $71.95^{\mathrm{a}}(20.67)$ & $71.14^{\mathrm{a}}(17.16)$ \\
Post grammar & $71.14^{\mathrm{a}}(18.96)$ & $74.04^{\mathrm{a}}(13.80)$ \\
\hline
\end{tabular}

$M$ Mean, $S D$ standard deviation

a, Values with different superscripts are different at $p<.001$. Results are based on pairwise comparisons

contrasts showed that treatment students outperformed the control $(p<.001)$. Even though control students' improved compared to previous work, treatment students' improvement was significant.

\section{TOWL-4 and TEWL-III}

A separate ANCOVA also conducted for TOWL-4 and TEWL-III subtests with pre subtests as covariates, the post subtests as the dependent variable, and condition as fixed factor. No statistically significant difference was found for either $(F(1$, $79)=.03, p=.85$ and $(F(1,79)=.87, p=.73$, respectively; see Table 3$)$.

\section{Student confidence: scale reliability}

A principal components analysis with Varimax rotation was conducted (Field, 2018) and nine factors were extracted; an examination of items' loading and conceptual clarity led to a four-factor solution (affect $\alpha=.88$, text structure $\alpha=.78$, grammar $\alpha=.74$, and processes $\alpha=.67$ ).

\section{Student confidence: group differences}

A MANCOVA was conducted with four dependent variables (post affect, text structure, grammar, and processes), and four covariates with the pre factors, and with condition as a fixed factor (see Table 4). Assumptions were examined and met (Box's $M=12.14, F(10,30,597.610)=1.14, p=.32)$. There was no statistically significant difference for condition $(p=.18)$. 


\section{Student post-interviews}

A total of 10 students from the control group and 10 students from the treatment group were interviewed. In the following section, student responses to the interview are summarized per question.

\section{Explanation of procedural writing: control students}

Students from both groups were asked, "What is procedural writing." Eight out of 10 students in the control group answered with some variation of teaching someone how to do a skill or task by listing steps and materials. One student stated that procedural writing is, "If somebody wants to know the steps you can teach them the steps by writing them down on a piece of paper and you have to tell them the steps." Two out of the 10 students did not know what procedural writing meant.

\section{Explanation of procedural writing: treatment students}

Without prompting, all students in the treatment group responded that procedural writing entailed providing steps and explanations for the reader to follow in order to learn how to do a skill or task by listing steps and explanations to teach the reader the skill or task. One student stated, "[procedural writing] is where you write an informational writing so if the person doesn't know then you can tell them on a piece of paper with clear steps and explanations." Two out of ten students from the treatment group also hinted that elements (e.g., topic, purpose) were important to include.

\section{Components of strong procedural writing pieces: control students}

Eight students from the control group suggested that good writing pieces were dependent on having good handwriting, spacing, capital letters, punctuation, providing details, and putting forth a great deal of effort. Only two of the $10 \mathrm{stu}-$ dents interviewed insisted that good procedural writing pieces were dependent on clearly listing steps and materials so that readers could better understand how to do what the procedural writing piece taught.

\section{Components of strong procedural writing pieces: treatment students}

All students who were provided instruction in the intervention stated that in order for a procedural writing piece to be considered good, it must contain all of the elements needed for a strong beginning, middle, and end. Seven out of the 10 students readily listed the elements required for a strong beginning (topic, purpose/ importance, materials/skills); middle (steps and explanations); and ending (restate the purpose/importance, evaluation, message to the reader) without prompting. 
All students were able to recall the elements required for strong beginning, middle, and endings of procedural essays when provided minimal prompting.

\section{Difficulties children face when writing procedural papers: control students}

Most commonly, students from the control group stated they had difficulties with spelling and punctuation. Three students stated they struggled to make sure that all steps were listed in the correct order, provide examples, and generate ideas.

\section{Difficulties children face when writing procedural papers: treatment students}

Most students in the treatment group stated they struggled with procedural writing when they were not sure how to do the task. For example, one student explained he did not know all of the steps for washing a dog because his older sister usually does most of that task since their dog is a large German Shepard.

\section{Types and importance of revision strategies: control students}

For most students in the control group, revision entails, "Looking over [the paper], reread it, change it, check the spelling, check for capital letters, check for punctuation..." When asked how to teach a young child to revise their paper, one student stated, "First you have to write your paper, then you have check over it and make sure you have all of the words spelled right, and make sure they are in the right order, and that you are telling [the reader] exactly what to do." The revision process for students in the control group involved reviewing the paper for clarity and ensuring the grammar and mechanics of writing were completed accordingly. Most students explained that the teacher was responsible for showing them where their mistakes were and how to correct the mistakes.

\section{Types and importance of revision strategies: treatment students}

Most students from the treatment group stated that revision was part of the evaluate to revise step of the writing ladder. Each of the students explained their revision process included using a rubric to ensure the elements were in their paper (they received a 0 or 1 or 2 on their rubric) and by rewriting and adding forgotten elements into their paper. Two students expressed the importance of being truthful when completing the rubric. Three students stated that they struggled with including the elements (e.g., message to the reader). Next, students shared that they used SCIPS to ensure that spelling, capitalization, indentation, periods were included, and sentences made sense. Students in the treatment group stated the purpose of revision was to ensure the procedural writing piece was clear for readers and assure readers could understand. 


\section{Planning strategies used for procedural writing: control students}

Two of the 10 students in the control group described using a planning sheet to organize their thoughts before writing. Most students in the control group explained their planning process involved thinking in their head about the steps. Two students explained that their teacher modeled making a list when planning and one student stated that they also practiced planning as a class by making a list; however, when they write, they usually don't make a list, they simply think about all of the things they need and decide the order as they write.

\section{Planning strategies used for procedural writing: treatment students}

Treatment students described a distinct strategy for planning. All of the students articulated their planning procedure involved using FTAAP (Form, Topic, Audience, Author, Purpose), brainstorming, and a graphic organizer to organize their thoughts before writing. Students in the treatment group shared the tools to help them plan (e.g., graphic organizer, sentence frames).

\section{Confidence levels and challenges perceived during procedural writing tasks: control students}

When students were asked to share how confident they felt about writing a procedural paper (on a scale from 0 to 10 where 0 meant not at all confident, 5 so-so confident, and 10 very confident), the average confidence level reported by students in the control group was 8.6. Challenges that students encountered were related to handwriting quality, spelling, or forgetting the steps or materials required for the task. Two students reported writing procedural papers outside of the classroom. (e.g., one student wrote how to get a library card at the public library).

\section{Treatment students}

The average confidence level for students in the treatment group was 8.8. The one student who reported a confidence level of 5 out of 10 stated that his lack of confidence was due to spelling errors. Other challenges that students in the treatment group reported were related to not having experience with the topic, remembering the elements, or being honest when using the rubric to score the paper. Three students in the treatment group stated they wrote procedural papers outside of the classroom (e.g., one student wrote how to bake a cake at home). 


\section{Discussion}

The purpose of this study was to examine the effects of a PD on genre-based strategy instruction for procedural writing on second grade teachers' instructional implementation and on second-grade students' writing quality. The results of this Tier I instruction showed positive effects on students' writing with improvements on writing quality at posttest, transfer, and after collaborative practice with peers. Students of the experimental condition were able to explain the writing process and the purpose of writing compared to control; however, transfer to another genre (persuasion) and to a different subject (science) was a challenge.

Teachers positively commented on the components of the PD and on the coaching support. They found the use of videos that were part of the workshop helpful in better understanding the instructional components and delivery. Further, they appreciated the use of written feedback on their instruction as they were able to review the information and make immediate revisions in their delivery. These findings on the use of written feedback for coaching echo findings from previous work (Traga Philippakos, 2020; Traga Philippakos \& MacArthur, 2020; Philippakos, MacArthur \& Munsell, 2018; Shaha \& Ellsworth, 2013). Teachers welcome and find beneficial immediate feedback and specific comments for instructional revisions. There were no statistically significant differences on students' confidence and on teachers' confidence. Even though the number of teachers was small to examine such difference and draw conclusions, overall, teachers independently of condition were equally confident in their instruction.

The findings of this approach to instruction and PD echo findings on PD that addresses systematic instruction of writing. In the work by Harris and colleagues (2012), teachers were provided with lessons, observations, videos of instruction, and communication via email and phone. Similarly, in this study the inclusion of organized resources for teachers to use supported their pedagogical content knowledge on how to teach procedural writing. In this current work, though, the entire PD and coaching with explanations about the instructional approach and its components was conducted virtually. This study has implications both for instruction as well as research and policy considering the affordances of PD on writing through virtual avenues.

\section{Practical implications}

Teachers often express their lack of preparation to teach writing during their college attendance and the lack of PD on writing in their workplace (Troia \& Graham, 2016). The International Literacy Association (ILA) calls for teachers' ongoing professional growth. If this is the goal, the obstacle is the provision of high-quality PD in a cost-effective manner for schools and districts and in a feasible manner for teachers. The provision of online PD that includes components of theory, application, and ongoing coaching are promising. Challenges that may be related to funding, circumstances (e.g., pandemic in 2019), location (e.g., rural sites), and time (e.g., scheduling separate PD days in a year) may prevent planning for writing 
PD. However, online sessions support teachers' understanding about genre-based strategy instruction and they benefit from coaching that connects with immediate feedback for them to implement recommendations in the next lesson. Workshop sessions can take place during teachers' Professional Learning Communities (PLCs) to further support their collegial collaborations through shared expertise.

\section{Limitations and research implications}

In this work we did not include a measure of reading comprehension. Possibly, the challenge that students faced with transfer in science was because of their difficulty to understand the content due to lack of background knowledge (O'Reilly, Wang, \& Sabatini, 2019). Future research could control for background knowledge and include a measure of reading comprehension to examine whether the process of critical rereading for evaluation and dramatization supported students' visualization when reading and meaning making, and whether the process of notetaking for summarization affected reading comprehension.

In addition, students found especially challenging the transfer to science. Based on comments raters provided and their scoring, especially challenging was the reference to the reading. Students tended to directly copy all information without referencing it and without indicating there was a quote. Future research could examine how to best teach second graders how to reference information and avoid plagiarism. Also, future research could examine what is the optimal age for students to be introduced to this aspect of academic writing.

In this work we were restricted by the number of teachers in the collaborative site. It would have been far better statistically to have a larger number of classes in order to examine the effects of this work through nesting models. However, we were able to only work with one site and larger available samples are a condition for multilevel modeling (Maas \& Hos, 2005). Future research could examine the effects with a larger population of teachers and students.

Also, we did not examine this instructional approach without PD versus the instruction with the online PD model. This is because of practical and ethical reasons as we could not ask teachers to teach using a new instructional approach without support. In this work, we assured that all teachers taught the same genre; further teachers of the control group had received PD from the writing program they used and were coached by their reading/curriculum coordinator. For the same reasons and because of resources and funding limitations, since the location of the site was $7 \mathrm{~h}$ away from the researcher, there was no comparison between a face-to-face version of PD and this online format. This study addressed the question of whether online PD on writing could be effective in promoting high fidelity of implementation and student achievement. Thus, we tested first whether the PD led to high fidelity of implementation, which it did; we then tested student outcomes as further evidence of the quality of instruction. Future research can examine different PD models and formats. 
In this work we included sentence-level support within the editing stage of STS, and teachers modeled how to support students' writing by orally stating their sentences prior to writing them. Researchers have examined the effects of sentence combining on students' writing performance (e.g., Saddler \& Asaro-Saddler, 2009) and sentence combining has been also found to support learners' comprehension (Graham, \& Hebert, 2010). Future research could integrate systematic instruction on sentence-combining to examine effects of a more-structured approach to sentence development and editing on students' writing production and editing practices.

Further, we did not examine separately the effects of differentiated instruction even though there is a need to design and evaluate tiers of assessment and instruction in writing (e.g., Troia, 2015; Traga Philippakos \& Fitzpatrick, 2018). Future research could examine the effects of this online PD and instruction on whole-group and on small group settings and the differential needs for students who benefit from a Tier II or a Tier III structured approach.

Finally, we incorporated the use of exemplar videos. Teachers provided positive comments on the use of videos for their PD and on the recording of their instruction for coaching. They also requested more videos. Future research could examine the effects of videos on teachers' fidelity of implementation and on students' overall writing quality. Possibly a components' analysis of the PD features could investigate which components of this virtual PD model on genre-based strategy instruction are most effective.

In this study, though, the goal was to examine whether online PD on genre-based strategy instruction supports fidelity of implementation that leads to increased writing achievement. The results of this investigation show that virtual PD on genrebased strategy instruction for procedural writing is feasible and can support teachers' implementation and significantly improve second-grade students' writing performance immediately at posttest, and after 3 weeks of instruction at maintenance.

\section{References}

Allen, J. P., Pianta, R. C., Gregory, A., Mikami, A. Y., \& Lun, J. (2011). An interaction-based approach to enhancing secondary school instruction and student achievement. Science, 333(6045), 1034-1037.

Ball, D. L., \& Cohen, D. K. (1999). Developing practice, developing practitioners: Toward a practicebased theory of professional education. In G. Sykes \& L. Darling-Hammond (Eds.), Teaching as the learning profession: Handbook of policy and practice (pp. 3-32). Hoboken: Jossey Bass.

Bandura, A. (1999). A sociocognitive analysis of substance abuse: An agentic perspective. Psychological Science, 10(3), 214-217.

Berger, P., Maurer, R., \& Celli, G. B. (2018). Experimental design. Berlin: Springer.

Birman, B. F., Desimone, L., Porter, A. C., \& Garet, M. S. (2000). Designing professional development that works. Educational Leadership, 57(8), 28-33.

Calkins, L. M. (2006). Units of study for teaching writing, grades (pp. 3-5). Portsmouth: Heinemann.

Carrow-Woolfolk, K. (2011). Oral written language skills (OWLS-3) (3rd ed.). Torrance: Western Psychological Services.

Common Core State Standards Initiative (2010). Common core state standards for English language arts and literacy in history/social studies, science, and technical subjects. http://www.corestandards.org/ assets/CCSSI_ELA\%20Standards.pdf. Retrieved 10 October 2015.

Cornett, J., \& Knight, J. (2009). Research in coaching. In J. Knight (Ed.), Coaching: Approaches and perspectives (pp. 192-216). Thousand Oaks: Corwin Press. 
Cutler, L., \& Graham, S. (2008). Primary grade writing instruction: A national survey. Journal of Educational Psychology, 100(4), 907-919. https://doi.org/10.1037/a0012656.

Desimone, L., \& Garet, M. (2015). Best practices in teachers' professional development in the United States (Report). Psychology, Society, and Education, 7(3), 252-263. https://doi.org/10.25115/psye. v7i3.515.

Desimone, L. M. (2009). Improving impact studies of teachers' professional development: Toward better conceptualizations and measures. Educational Researcher, 38(3), 181-199. https://doi. org/10.3102/0013189X08331140.

Downer, J. T., Pianta, R. C., Fan, X., Hamre, B. K., Mashburn, A., \& Justice, L. (2011). Effects of webmediated teacher professional development on the language and literacy skills of children enrolled in prekindergarten programs. NHSA Dialog: A Research-to-Practice Journal for the Early Childhood Field., 14(4), 189-212. https://doi.org/10.1080/15240754.2011.613129.

Englert, C. S., Raphael, T. E., Anderson, L. M., Anthony, H. M., \& Stevens, D. D. (1991). Making strategies and self-talk visible: Writing instruction in regular and special education classrooms. American Educational Research Journal, 28(2), 337-372. https://doi.org/10.3102/00028312028002337.

Festas, I., Oliveira, A., Rebelo, J., Damião, M., Harris, K., \& Graham, S. (2015). Professional development in self-regulated strategy development: Effects on the writing performance of eighth grade Portuguese students. Contemporary Educational Psychology, 40, 17-27. https://doi.org/10.1016/j. cedpsych.2014.05.004.

Field, A. P. (2018). Discovering statistics using IBM Statistics SPSS (5th ed.). London, UK: Sage.

Field, A. P. (2009). Discovering statistics using SPSS (3rd ed.). London: Sage.

Furtak, E. M., Ruiz-Primo, M. A., Shemwell, J. T., Ayala, C. C., Brandon, P. R., Shavelson, R. J., \& Yue, Y. (2008). On the fidelity of implementing embedded formative assessments and its relation to student learning. Applied Measurement in Education, 21(1), 360-389. https://doi.org/10.1080/08957 340802347852 .

Garet, M., Porter, A., Desimone, L., Birman, B., \& Yoon, K. (2001). What makes professional development effective? Results from a national sample of teachers. American Educational Research Journal, 38(4), 915-945. https://doi.org/10.3102/00028312038004915.

Gilbert, J., \& Graham, S. (2010). Teaching writing to elementary students in grades 4-6: A national survey. Elementary School Journal, 10(4), 494-518. https://doi.org/10.1086/651193.

Good, R. H., \& Kaminski, R. A. (Eds.). (2002). Dynamic indicators of basic early literacy skills, 6th edn. Institute for the Development of Educational Achievement. Available: http://dibels.uoregon.edu/.

Graham, S., Bolinger, A., Olson, C., D’Aoust, C. MacArthur, C., McCutchen, D., \& Olinghouse, N. (2012). Teaching elementary school students to be effective writers. Retrieved from: http://ies. ed.gov/ncee/wwc/PracticeGuide.aspx?sid=17.

Graham, S., Bruch, J., Fitzgerald, J., Friedrich, L., Furgeson, J., Greene, K., Kim, J., Lyskawa, J., Olson, C. B., \& Smither Wulsin, C. (2016). Teaching secondary students to write effectively (NCEE 2017-4002). Washington, DC: National Center for Education Evaluation and Regional Assistance (NCEE), Institute of Education Sciences, U.S. Department of Education. Retrieved from the NCEE website: http://whatworks.ed.gov.

Graham, S., \& Harris, K. R. (1989). Improving learning disabled students' skills at composing essays: Self-instructional strategy training. Exceptional Children, 56(3), 201-214. https://doi. org/10.1177/001440298905600305.

Graham, S., Harris, K. R., \& Chambers, A. B. (2016). Evidence-based practice and writing instruction: A review of reviews. In C. A. MacArthur, S. Graham, \& J. Fitzgerald (Eds.), Handbook of writing research (2nd ed., pp. 211-226). New York: Guilford Press.

Graham, S., Harris, K. R., Fink, B., \& MacArthur, C. (2001). Teacher efficacy in writing: A construct validation with primary grade teachers. Scientific Study of Reading, 5(2), 177-202. https://doi. org/10.1207/S1532799Xssr0502_3.

Graham, S., \& Hebert, M. (2010). Writing to read: A meta-analysis of the impact of writing and writing instruction on reading. Harvard Educational Review, 81(4), 710-744. https://doi.org/10.17763/ haer.81.4.t2k0m13756113566.

Graham, S., Liu, X., Aitken, A., Ng, C., Bartlett, B., Harris, K., \& Holzapfel, J. (2018). Effectiveness of literacy programs balancing reading and writing instruction: A meta-analysis. Reading Research Quarterly, 53(3), 279-304. https://doi.org/10.1002/rrq.194.

Graham, S., McKeown, D., Kiuhara, S. A., \& Harris, K. R. (2012). A meta-analysis of writing instruction for students in the elementary grades. Journal of Educational Psychology, 104(4), 879-896. https:// doi.org/10.1037/a0029939. 
Graham, S., \& Perin, D. (2007). What we know, what we still need to know: Teaching adolescents to write. Scientific Studies of Reading, 11(4), 313-335. https://doi.org/10.1080/10888430701530664.

Graham, S., \& Perin, D. (2007). Writing next: Effective strategies to improve writing of adolescents in middle and high schools-A report to Carnegie Corporation of New York. Washington, DC: Alliance for Excellent Education.

Gresham, F. M. (1989). Assessment of treatment integrity in school consultation and prereferral intervention. School Psychology Review, 18(1), 37-50.

Guskey, T. R. (2002). Professional development and teacher change. Teachers and Teaching: Theory and Practice, 8(1), 382-391. https://doi.org/10.1080/135406002100000512.

Guskey, T. R., \& Huberman, M. (1995). Professional development in education: New paradigms and practices. New York: Teachers College Press.

Hallgren, K. A. (2012). Computing inter-rater reliability for observational data: An overview and tutorial. Tutorials in Quantitative Methods for Psychology, 8(1), 23-34. https://doi.org/10.20982/ tqmp.08.1.p023.

Hammill, D. D., \& Larsen, L. (2009). Test of written language (TOWL-4) (4th ed.). Austin: PROED.

Harris, K. R., \& Graham, S. (2009). Self-regulated strategy development in writing: Premises, evolution, and the future. British Journal of Educational Psychology Monograph Series II, 2(6), 113-135. https://doi.org/10.1348/978185409X422542.

Harris, K. R., Graham, S., \& Adkins, M. (2015). Practice-based professional development and self-regulated strategy development for tier 2, at-risk writers in second grade. Contemporary Educational Psychology, 40(5), 5-6. https://doi.org/10.1016/j.cedpsych.2014.02.003.

Harris, K., Lane, K., Graham, S., Driscoll, S., Sandmel, K., Brindle, M., \& Schatschneider, C. (2012). Practice-based professional development for self-regulated strategies development in writing: A randomized controlled study. Journal of Teacher Education, 63, 103-119. https://doi. org/10.1177/0022487111429005.

Hayes, J. R. (1996). A new framework forunderstandingcognition and affect in writing. In C. M. Levy \& S. Ransdell (Eds.), Thescienceof writing (pp. 1-27). Hillsdale: Lawrence Erlbaum.

Hayes, J. R. (2004). What triggers revision? In L. Allal, L. Chanquoy, \& P. Largy (Eds.), Revision, cognition, and instructional processes (pp. 9-20). Dordrecht: Kluwer Academic Publishers.

Hayes, J. R. (2006). New directions in writing theory. In C. A. MacArthur, S. Graham, \& J. Fitzgerald (Eds.), Handbook of writing research (pp. 28-40). New York: Guilford Press.

Hidi, S., \& Boscolo, P. (Eds.). (2006). Writing and motivation. ProQuest Ebook Central https://ebook central.proquest.com.

Hresko, W., Herron, S., Peak, P., \& Hicks, D. L. (Eds.). (2012). Test of early written language (TEWL-4). New York: Pearson.

Joyce, B., \& Showers, B. (2002). Student achievement through staff development. ProQuest Ebook Central https://ebookcentral.proquest.com.

Kennedy, M. M. (2016). How does professional development improve teaching? Review of Educational Research, 86(4), 945-980. https://doi.org/10.3102/0034654315626800.

Maas, C. J. M., \& Hox, J. J. (2005). Sufficient sample sizes for multilevel modeling. Methodology, 1(3), 86-92. https://doi.org/10.1027/1614-2241.1.3.86.

MacArthur, C. A. (2011). Strategies instruction. In K. R. Harris, S. Graham, \& T. Urdan (Eds.), Educational psychology handbook, vol. 3, Applications of educational psychology to learning and teaching (pp. 379-401). Washington: American Psychological Association.

MacArthur, C. A., Philippakos, Z. A., \& Ianetta, M. (2015). Self-regulated strategy instruction in college developmental writing. Journal of Educational Psychology, 107(3), 855-867.

Martin, J. R., \& Rose, D. (2012). Learning to write, reading to learn: Genre, knowledge and pedagogy in the Sydney School. London: Equinox Publishing Limited.

McCarthey, S. J., \& Geoghegan, C. M. (2016). The role of professional development for enhancing writing instruction. In C. A. MacArthur, S. Graham, \& J. Fitzgerald (Eds.), Handbook of writing research (2nd ed., pp. 330-348). New York: Guilford Press.

McKeown, D., Brindle, M., Harris, K., Graham, S., Collins, A., \& Brown, M. (2016). Illuminating growth and struggles using mixed methods: Practice-based professional development and coaching for differentiating SRSD instruction in writing. Reading and Writing, 29(6), 1105-1140. https://doi. org/10.1007/s11145-016-9627-y.

McKeown, D., Fitzpatrick, E., Brown, M., Brindle, M., Owens, J., \& Hendrick, R. (2019). Urban teachers' implementation of SRSD for persuasive writing following practice-based professional 
development: Positive effects mediated by compromised fidelity. Reading and Writing, 32(6), 14831506. https://doi.org/10.1007/s11145-018-9864-3.

National Assessment of Educational Progress: An overview of NAEP. (2009). Washington, D.C.: National Center for Education Statistics, Institute of Education Sciences, U.S. Dept. of Education.

National Commissionon Writing in America's Schools and Colleges. (2003). The neglected " $R$ ": The need for a writing revolution. New York: The College Board.

Neuman, S., \& Cunningham, L. (2009). The impact of professional development and coaching on early language and literacy instructional practices. American Educational Research Journal, 46(2), 532566. https://doi.org/10.3102/0002831208328088.

Newton, D., \& Ellis, A. (2005). Effective implementation of e-learning: A case study of the Australian army. Journal of Workplace Learning, 17(5), 385-397. https://doi.org/10.1108/136656205106067 97.

O'Reilly, T., Wang, Z., \& Sabatini, J. (2019). How much knowledge is too little? When a lack of knowledge becomes a barrier to comprehension. Psychological Science, 30(9), 1344-1351. https://doi. org/10.1177/0956797619862276.

Pajares, F. (1996). Self-efficacy beliefs in academic settings. Review of Educational Research, 66(4), 543-578.

Philippakos, Z. A. (2017). Giving feedback: Preparing students for peer review and self-evaluation. The Reading Teacher, 71, 13-22. https://doi.org/10.1002/trtr.1568.

Philippakos, Z. (2018). Using a task analysis process for reading and writing assignments. Reading Teacher, 72(1), 107-114. https://doi.org/10.1002/trtr.1690.

Philippakos, Z. A., \& MacArthur, C. A. (2016a). The effects of giving feedback on the persuasive writing of fourth- and fifth-grade students. Reading Research Quarterly, 51, 419-433. https://doi. org/10.1002/rrq.149.

Philippakos, Z. A., \& MacArthur, C. A. (2016b). The use of genre-specific evaluation criteria for revision. Language and Literacy Spectrum, 2(1), 41-52.

Philippakos, Z. A., \& Moore, N. (2017). The literacy coach's role in supporting teachers' implementation of the common core state standards in writing. In Lawrence, S. (Ed.), Literacy program evaluation and development initiatives for P-12 teaching, (pp. 114-137). https://doi.org/10.4018/978-1-52250669-0.ch007.

Philippakos, Z. A., \& MacArthur, C. A. (2020). Developing strategic, young writers through genre instruction: Resources for grades K-2. New York: Guilford Press.

Philippakos. Z. A., MacArthur, C. A., \& Coker, D. L. (2015). Developing strategic writers through genre instruction: Resources for grades 3-5. Guilford Press.

Philippakos, Z. A., Overly, M., Riches, C., Grace, L., \& Jones, W. (2018). Supporting professional development on writing strategy instruction: Listening to the voices of collaborators as carriers of change. School-University Partnerships, 11, 64-77. Retrieved from: https://search.proquest.com/ openview/799ecb702d7b534e8e275de783e2ea86/1?pq-origsite=gscholar\&cbl=4527887.

Powell, D. R., Diamond, K. E., Burchinal, M. R., \& Koehler, M. J. (2010). Effects of an early literacy professional development intervention on Head Start teachers and children. Journal of Educational Psychology., 102(2), 299-312.

Prior, P. (2006). A sociocultural theory of writing. In C. A. MacArthur, S. Graham, \& J. Fitzgerald (Eds.), Handbook of writing research (pp. 54-66). New York: Guilford Press.

Psychological Corporation. (2009). Wechsler individual achievement test (WIAT-III) (3rd ed.). New York: Psychological Corp.

Reinke, W. M., Stormont, M., Herman, K. C., \& Newcomer, L. (2014). Using coaching to support teacher implementation of classroom-based interventions. Journal of Behavioral Education, 23(1), $150-167$.

Rose, D. (2016). New developments in genre-based literacy pedagogy. In C. A. MacArthur, S. Graham, \& J. Fitzgerald (Eds.), Handbook of writing research (pp. 227-242). New York: Guilford Press.

Roth, K., Garnier, H., Chen, C., Lemmens, M., Schwille, K., \& Wickler, N. (2011). Videobased lesson analysis: Effective science PD for teacher and student learning. Journal of Research in Science Teaching, 48(1), 117-148. https://doi.org/10.1002/tea.20408.

Saddler, B., \& Asaro-Saddler, K. (2009). Writing better sentences: Sentence-combining instruction in the classroom, preventing school failure. Alternative Education for Children and Youth, 54(3), 159-163. https://doi.org/10.1080/10459880903495851.

Schoonen, R. (2005). Generalizability of writing scores: An application of structural equation modeling. Language Testing, 22(1), 1-30. https://doi.org/10.1191/02655322051t295oa. 
Shaha, S. H., \& Ellsworth, H. (2013). Predictors of success for professional development: Linking student achievement to school and educator successes through on-demand, online professional learning. Journal of Instructional Psychology, 40, 19-26.

Showers, B., Joyce, B., \& Bennett, B. (1987). Synthesis of research on staff development: A framework for future study and a state-of-the-art analysis. Educational Leadership, 45, 77-87.

Stevens, J. P. (2002). Applied multivariate statistics for the social sciences (4th ed.). Hillsdale: Lawrence Erlbaum.

Strauss, A. L., \& Corbin, J. M. (1990). Basics of qualitative research: Grounded theory procedures and techniques. Newbury Park, Calif: Sage Publications.

Tabachnick, B. G., \& Fidell, L. S. (2007). Using multivariate statistics (5th ed.). Needham: Allyn \& Bacon Inc.

Tallerico, M. (2014). District issues-Administrators at all levels involved in teachers' professional development. In L. E. Martin, S. Kragler, D. J. Quatroche, \& K. L. Bauserman (Eds.), Handbook of professional development in education: Successful models and practices, preK-12. New York: The Guilford Press.

Taylor, J., Roth, K., Wilson, C., Stuhlsatz, M., \& Tipton, E. (2017). The effect of an analysis-of-practice videocase-based, teacher professional development program on elementary students' science achievement. Journal of Research on Educational Effectiveness, 10(2), 241-271. https://doi. org/10.1080/19345747.2016.1147628.

Tierney, R. J., \& Shanahan, T. (1991). Research on the reading-writing relationship: Interactions, transactions, and outcomes. In R. Barr, M. L. Kamil, P. Mosenthal, \& P. D. Pearson (Eds.), Handbook of reading research (Vol. II, pp. 246-280). London: Longman.

Traga Philippakos, Z. A. (under review). Guidelines for effective professional development on genrebased strategy instruction: Principals' voices.

Traga Philippakos, Z. A. (2019). Effects of strategy instruction with an emphasis on oral language and dramatization on the quality of first graders' procedural writing. Reading \& Writing Quarterly, 35(5), 409-426. https://doi.org/10.1080/10573569.2018.1547233.

Traga Philippakos, Z. A. (2020). A yearlong, professional development model on genre-based strategy instruction on writing. The Journal of Educational Research, 113(3), 177-190. https://doi. org/10.1080/00220671.2020.1767531.

Traga Philippakos, Z. A., \& Fitzpatrick, E. (2018). A proposed tiered model of assessment in writing instruction: Supporting all student-writers. Insights into Learning Disabilities: From prevailing theories to validated approaches, 55(2), 149-174.

Traga Philippakos, Z., Macarthur, C., \& Munsell, S. (2018). Collaborative reasoning with strategy instruction for opinion writing in primary grades: Two cycles of design research. Reading \& Writing Quarterly, 34(6), 485-504. https://doi.org/10.1080/10573569.2018.1480438.

Traga Philippakos, Z. A., Robinson, L., \& Munsell, S. (2018). The effects of writing strategy instruction on K to 2 students' opinion and procedural writing. American Reading Forum Conference Proceedings, 40, 1-25.

Traga Philippakos, Z. A., \& MacArthur, C. A. (2020). Integrating collaborative reasoning and strategy instruction to improve second graders' opinion writing. Reading \& Writing Quarterly. 36(4), 379395. https://doi.org/10.1080/10573569.2019.1650315.

Troia, G. (2015). Writing instruction within a response to intervention framework: Prospects and challenges for elementary and secondary classrooms. In C. MacArthur, S. Graham, \& J. Fitzgerald (Eds.), Best practices in writing instruction (2nd ed., pp. 403-428). New York: Guilford.

Troia, G. A., \& Graham, S. (2016). Common core writing and language standards and aligned state assessments: A national survey of teacher beliefs and attitudes. Reading and Writing: An Interdisciplinary Journal, 29(9), 1719-1743. https://doi.org/10.1007/s11145-016-9650-z.

Weinfurt, K. P. (1995). Multivariate analysis of variance. In L. Grimm \& P. Yarnold (Eds.), Reading and understanding multivariate statistics. Washington: American Psychological Association.

Publisher's Note Springer Nature remains neutral with regard to jurisdictional claims in published maps and institutional affiliations. 